\title{
Visible Light-Induced Cytotoxicity of Ru,Os-Polyazine Complexes Towards Rat Malignant Glioma
}

Jie Zhu $\dagger^{\mathrm{a}}$, Anthony Dominijanni ${ }^{\mathrm{b}}$, José Á. Rodríguez-Corrales ${ }^{\mathrm{a}}$, Reece Prussin ${ }^{\mathrm{b}}$, Zongmin $\mathrm{Zhao}^{\mathrm{c}}$,Tinghui $\mathrm{Li}^{\mathrm{a}}$, John L. Robertson* ${ }^{\mathrm{b}}$ and Karen J. Brewer* $\star^{\mathrm{a}}$

\begin{abstract}
Transition metal complexes capable of visible light-triggered cytotoxicity are appealing potential candidates for photodynamic therapy (PDT) of cancer. Two monometallic polyazine complexes, $\left[\left(\mathrm{Ph}_{2} \text { phen }\right)_{2} \mathrm{Ru}(\mathrm{dpp})\right]^{2+}(\mathbf{1})$ and $\left[\left(\mathrm{Ph}_{2} \text { phen }\right)_{2} \mathrm{Os}(\mathrm{dpp})\right]^{2+}(\mathbf{2}) \quad\left(\mathrm{Ph}_{2}\right.$ phen = 4,7-diphenyl-1,10phenanthroline; $\mathrm{dpp}=2,3$-bis(2-pyridyl)pyrazine), were synthesized, characterized and studied as light activated drugs to kill rat malignant glioma F98 cells. Compounds $\mathbf{1}$ and $\mathbf{2}$ display strong absorption in visible spectrum, oxygen-mediated DNA and BSA photocleavage and significant photocytotoxicity under blue light irradiation along with negligible activity in the dark. Both compounds show approximately five-fold higher cytotoxicity than the traditional chemotherapeutic drug cisplatin. Furthermore, compound $\mathbf{2}$ shows promising photocytotoxicity in F98 rat malignant glioma cells within the phototherapeutic window with an $\mathrm{IC}_{50}$ value of (86.07 \pm 8.48$) \mu \mathrm{M}$ under red light $(625 \mathrm{~nm})$ irradiation.
\end{abstract}

\section{Introduction}

Photodynamic therapy (PDT) is a noninvasive treatment that uses a photosensitizer (PS), low energy light, and in most cases ${ }^{3} \mathrm{O}_{2}$ to produce photocytotoxic reactive oxygen species (ROS) to damage neoplastic cells. ${ }^{1}$ The generation of ${ }^{1} \mathrm{O}_{2}$ is believed to occur via energy transfer from the excited photosensitizer (Figure 1). ${ }^{2}$ This minimally-invasive, light-activated therapeutic treatment allows for accurate targeting of tumor cells, and reduces side effects associated with systemic chemotherapy. ${ }^{3}$ A variety of organic PDT agents have been approved for clinical use or are undergoing clinical trials, including porphyrins, chlorins and phthalocyanines. ${ }^{4}$ However, these conventional PDT agents suffer from dark toxicity, prolonged skin sensitivity and hepatotoxicity, greatly limiting their widespread application. ${ }^{5}$ Transition metal complexes that 
have tunable coordination environments and varied spectral and redox properties are promising candidates as the next generation of PDT agents. ${ }^{6}$ Among them, ruthenium complexes with polypyridyl ligands, such as derivatives of $\left[\mathrm{Ru}(\mathrm{bpy})_{3}\right]^{2+}(\mathrm{bpy}=2,2$ '-bipyridine), have been widely studied due to their active interaction with cellular components (DNA, RNA, and proteins). ${ }^{7}$ Ideally, PDT drugs need to be operative in the phototherapeutic window (600-900 $\mathrm{nm})$, where light can efficiently penetrate bodily tissues. ${ }^{8}$ However, few reported metal complexes were able to be photoactivated with low energy light. ${ }^{9}$ Thus in this promising research area, it is still highly desirable to find novel PDT agents with enhanced activity within the phototherapeutic window and towards aggressive tumors such as high-grade malignant glioma (MG).

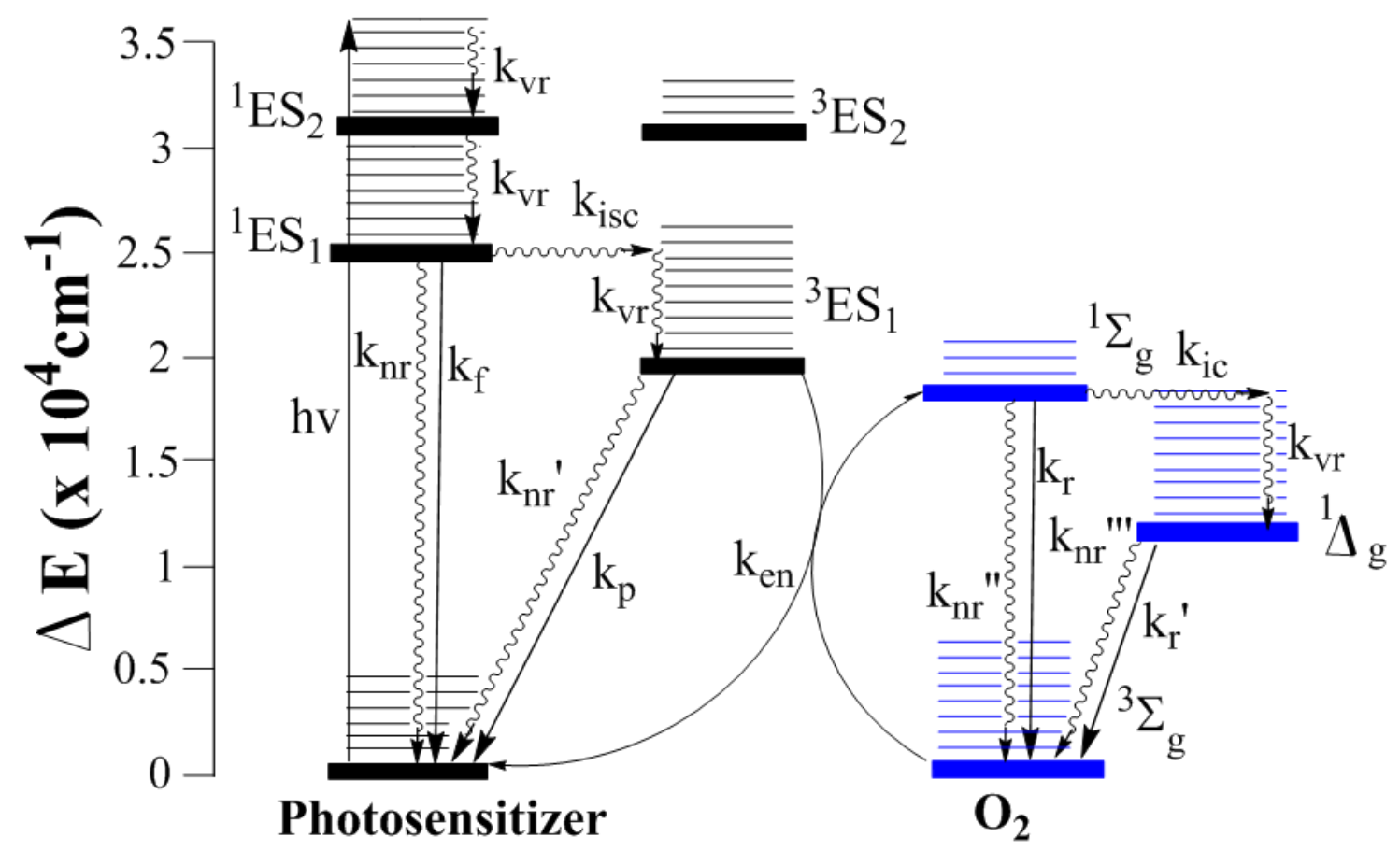

Figure 1. State diagram illustrating the mechanisms of action for drugs displaying oxygen-dependent photodynamic action with k's (rate constants) for f (fluorescence), $\mathrm{p}$ (phosphorescence), $\mathrm{r}$ (radiative), $\mathrm{nr}$ (nonradiative), ic (internal conversion), isc (intersystem crossing), en (energy transfer) and vr (vibration). The electronic state ${ }^{1} \Delta_{\mathrm{g}}$ is observed at $1270 \mathrm{~nm}$ or $0.97 \mathrm{~V},{ }^{1} \sum_{\mathrm{g}}$ is estimated at $1.6-1.8 \mathrm{~V}$ but is short-lived.

Aggressive, infiltrative MGs make up approximately $1.35 \%$ of the total cancer cases reported in $2013 .{ }^{10}$ The survival rate for MG is extremely low, with only $17.7 \%$ living beyond 1 -year of 
diagnosis. ${ }^{11}$ The lack of external cellular growth control, infiltrative growth pattern, and resistance to host immunologic defences make MG cells a particularly aggressive therapeutic challenge. MGs are resistant to virtually all forms of traditional cancer therapy, including radiation therapy, chemotherapy, and ablative surgical therapy as well as combinations of these procedures. Upon initial diagnosis of glioblastoma multiforme (GBM), standard treatment consists of maximal surgical resection, radiotherapy, and concomitant/adjuvant chemotherapy with temozolomide (TMZ). ${ }^{12}$ However, over $95 \%$ of all patients with MG die within two years, regardless of the type of therapy used. ${ }^{13} \mathrm{TMZ}$, as the most commonly used chemotherapeutic agent in the therapy of $\mathrm{GBM}$, has an $\mathrm{IC}_{50}$ (concentration resulting in cell viability of $50 \%$ of control) of approx. $200 \mu \mathrm{M}$ towards U87-MG malignant glioma cells. ${ }^{14}$ Thus, new treatments to high-grade MG are urgently needed to address and alleviate the limitations of current therapeutic approaches and improve patient survival rates.

Transition metal complexes are actively being developed as PDT agents. ${ }^{15}$ Monometallic compounds are very attractive due to their simple synthetic approach and concise structure. ${ }^{16}$ Common approaches employed in the design of monometallic PDT agents include ligand variation/modification and metal center variation. Metal center/ligand variation allows for tuning of redox, spectroscopic and photophysical properties with ligand modification allowing for added targeting ability. ${ }^{9 a, 17}$ Herein, we report the design of a new set of $\left[\left(\mathrm{Ph}_{2} \text { phen }\right)_{2} \mathrm{M}(\mathrm{dpp})\right]^{2+}$ $\left(\mathrm{Ph}_{2}\right.$ phen $=4,7$-diphenyl-1,10-phenanthroline; $\mathrm{dpp}=2,3$-bis(2-pyridyl)pyrazine; $\left.\mathrm{M}=\mathrm{Ru} / \mathrm{Os}\right)$ polyazine complexes with light-promoted cytotoxicity in rat malignant glioma F98 cells. To the best of our knowledge, compounds $\mathbf{1}$ and $\mathbf{2}$ are the first reported transition metal complexes that display PDT activity towards gliomas cells. These compounds show approximately five-fold higher cytotoxicity than the traditional chemotherapeutic drug cisplatin. Furthermore, compound 2 is the first complex to show photocytotoxicity in malignant gliomas within the phototherapeutic window. Photoactivity of the compounds was studied in DNA and bovine serum albumin (BSA) as model biomolecules, which are potential targets for these phototoxic species. 


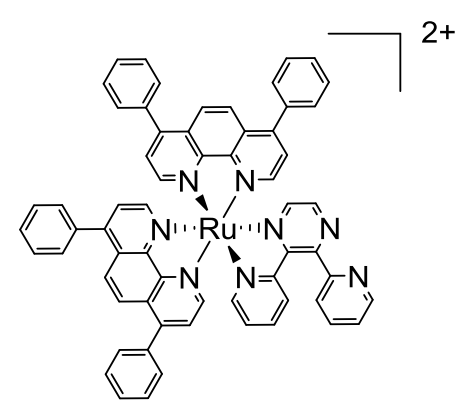

1. $\left[\left(\mathrm{Ph}_{2} \text { phen }\right)_{2} \mathrm{Ru}(\mathrm{dpp})\right]^{2+}$

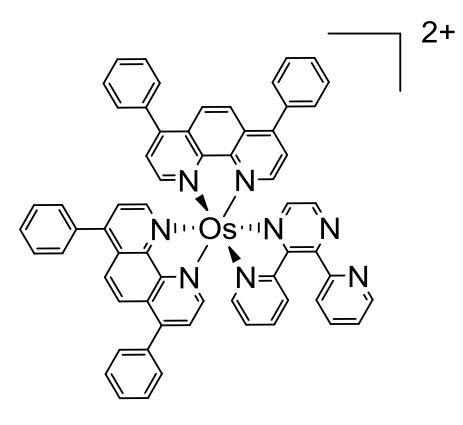

2. $\left[\left(P h_{2} \text { phen }\right)_{2} \mathrm{Os}(\mathrm{dpp})\right]^{2+}$

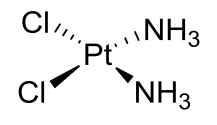

3. cis- $\left[\mathrm{Pt}\left(\mathrm{NH}_{3}\right)_{2} \mathrm{Cl}_{2}\right]$

Figure 2. Structural representations of metal compounds in this study. $\mathrm{Ph}_{2}$ phen =4,7-diphenyl-1,10phenanthroline; dpp =2,3-bis(2-pyridyl)pyrazine

\section{Experimental Section}

Materials and methods. $\left[\left(\mathrm{Ph}_{2} \text { phen }\right)_{2} \mathrm{RuCl}_{2}\right]$ and $\left[\left(\mathrm{Ph}_{2} \text { phen }\right)_{2} \mathrm{OsCl}_{2}\right]$ were synthesized as previously reported. ${ }^{18} \mathrm{Ph}_{2}$ phen, dpp, $\mathrm{RuCl}_{3} \cdot 3 \mathrm{H}_{2} \mathrm{O}, \mathrm{Bu}_{4} \mathrm{NPF}_{6}, \mathrm{NH}_{4} \mathrm{PF}_{6}$ and cisplatin, cis$\left[\mathrm{Pt}\left(\mathrm{NH}_{3}\right)_{2} \mathrm{Cl}_{2}\right]$, were purchased from Alfa Aesar. Solvents were HPLC grade. All materials were used as received without further purification unless otherwise noted. Sephadex LH-20 was purchased from GE healthcare Biosciences Corporation. Supercoiled pUC19 plasmid DNA was purchased from Bayou Biolabs. Lamba/Hind III markers was purchased from Promega Corporation. Bovine serum albumin (BSA) was purchased from Sigma-Aldrich. NuPAGETM Novex ${ }^{\mathrm{TM}}$ 4-12\% Bis-Tris Protein Gels $(1.0 \mathrm{~mm}, 15$-well) was purchased from Invitrogen. F98 malignant glioma rat cancer cells were purchased from American Type Culture Collection (ATCC ${ }^{\circledR}$ CRL-2397 ${ }^{\mathrm{TM}}$ ) and used in toxicity studies at passage 7. Cells were seeded in a Thermo Scientific 1300 Series A2 sterile hood and incubated at $37^{\circ} \mathrm{C}$ with $5 \% \mathrm{CO}_{2}$. Dulbecco's Modified Eagle's Medium (DMEM), Fetal Bovine Serum (FBS), penicillin-streptomycin antibiotic solutions were obtained from ATCC ${ }^{\circledR} .0 .05 \%$ Trypsin-EDTA and phosphate buffer solutions (PBS) were purchased from Life Technologies, while $75 \mathrm{~cm}^{2}$ tissue flask, serological pipettes and $15 \mathrm{~mL} / 50 \mathrm{~mL}$ centrifuge tubes were obtained from Fisher Scientific. Cells were collected with a Thermo Scientific Sorvall ST 8R refrigerated centrifuge and counted in a Beckman Coulter Vi-Cell cell viability analyzer. Samples were submitted to Galbraith Laboratories, Inc., for elemental analysis. 
Synthesis of $\left[\left(\mathbf{P h}_{2} \text { phen }\right)_{2} \mathbf{R u}(\mathbf{d p p})\right]\left(\mathbf{P F}_{6}\right)_{2} \quad$ (1). The monometallic complex, $\left[\left(\mathrm{Ph}_{2} \text { phen }\right)_{2} \mathrm{Ru}(\mathrm{dpp})\right]\left(\mathrm{PF}_{6}\right)_{2}$ was synthesized as previously reported using a building block approach (Figure 3). ${ }^{18}\left[\left(\mathrm{Ph}_{2} \text { phen }\right)_{2} \mathrm{RuCl}_{2}\right](0.56 \mathrm{~g}, 0.67 \mathrm{mmol})$ and excess dpp (0.54 g, $\left.2.4 \mathrm{mmol}\right)$ were heated at reflux in $30 \mathrm{~mL}$ of $70: 30 \mathrm{EtOH} / \mathrm{H}_{2} \mathrm{O}$ for ca. $2 \mathrm{~h}$. The reaction mixture was cooled to R.T. and aqueous saturated $\mathrm{NH}_{4} \mathrm{PF}_{6}$ was added to induce precipitation as a $\mathrm{PF}_{6}{ }^{-}$salt. The solid was collected by vacuum filtration, dissolved in a minimal amount of 2:3 $\mathrm{CH}_{3} \mathrm{CN} /$ toluene and purified by alumina chromatography using 2:3 $\mathrm{CH}_{3} \mathrm{CN} /$ toluene eluent. The leading orange band was collected, the solvent was removed under vacuum, and the complex was flash precipitated from dry acetone in diethyl ether, with $0.69 \mathrm{~g}$ of desired product in $80 \%$ yield. Anal. Calc. for $\mathrm{C}_{62} \mathrm{H}_{42} \mathrm{~F}_{12} \mathrm{~N}_{8} \mathrm{P}_{2} \mathrm{Ru}(\mathrm{MW}=1290.07 \mathrm{~g} / \mathrm{mol}): \mathrm{C}, 57.72 \%$; H, 3.28\%; N, 8.69\%. Found: C,57.59\%; H, 3.26\%; N,8.82\%. HPLC-MS (Figure S1) and ESI-MS: $\left[\mathrm{M}-2\left(\mathrm{PF}_{6}\right)\right]^{2+}, \mathrm{m} / \mathrm{z}=500.13$.

Synthesis of $\left[\left(\mathbf{P h}_{2} \text { phen }\right)_{2} \mathbf{O s}(\mathbf{d p p})\right]\left(\mathbf{P F}_{6}\right)_{2}(2)$. The monometallic complex, $\left[\left(\mathrm{Ph}_{2} \text { phen }\right)_{2} \mathrm{OsCl}_{2}\right]$ was synthesized similar to compound 1, except changing the solvent to ethylene glycol (Figure 3). $\left[\left(\mathrm{Ph}_{2} \text { phen }\right)_{2} \mathrm{OsCl}_{2}\right](0.31 \mathrm{~g}, 0.33 \mathrm{mmol})$ and excess dpp $(0.23 \mathrm{~g}, 0.99 \mathrm{mmol})$ were heated at reflux in $25 \mathrm{~mL}$ of ethylene glycol for ca. $2 \mathrm{~h}$ under Ar. The reaction mixture was cooled to R.T. and aqueous saturated $\mathrm{NH}_{4} \mathrm{PF}_{6}$ was added to induce precipitation as a $\mathrm{PF}_{6}^{-}$salt. The solid was collected by vacuum filtration, dissolved in a minimal amount of 2:3 $\mathrm{CH}_{3} \mathrm{CN} /$ toluene and purified by alumina chromatography using 2:3 $\mathrm{CH}_{3} \mathrm{CN} /$ toluene eluent. The second brown band was collected; solvent was removed under vacuum, and the complex was flash precipitated from dry acetone in diethyl ether, with $0.32 \mathrm{~g}$ of desired product in $70 \%$ yield. Anal. Calc. for $\mathrm{C}_{62} \mathrm{H}_{42} \mathrm{~F}_{12} \mathrm{~N}_{8} \mathrm{P}_{2} \mathrm{Os}(\mathrm{MW}=1379.23 \mathrm{~g} / \mathrm{mol})$ : C, 53.99\%; H, 3.07\%; N, 8.12\%. Found: C, 54.13\%; H, $3.35 \%$; N, 8.04\%. HPLC-MS (Figure S2) and ESI-MS: $\left[\mathrm{M}-2\left(\mathrm{PF}_{6}\right)\right]^{2+}, \mathrm{m} / \mathrm{z}=545.16$ 


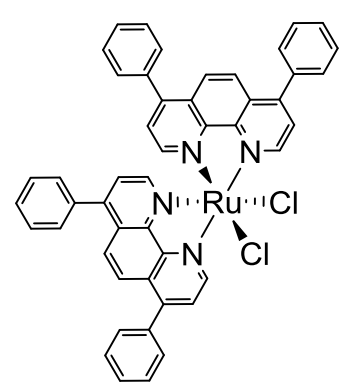

1 equiv

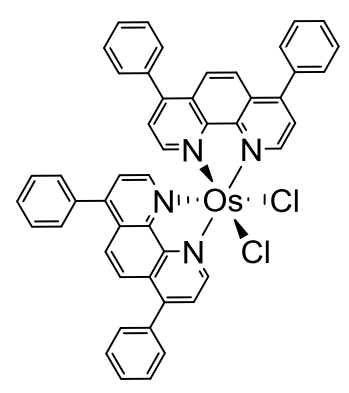

1 equiv

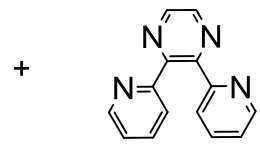

3 equiv

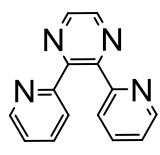

3 equiv

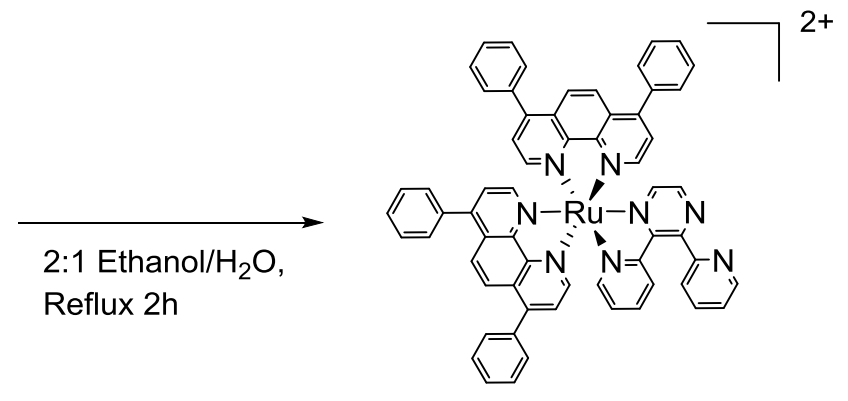

Figure 3. Synthetic scheme for compounds 1 and 2.

ESI-TOF Mass Spectrometry. ESI was performed by an Agilent Technologies 6220 Accurate-Mass TOF LC-MS with a dual ESI source to obtain high resolution mass spectral data. Samples were dissolved in HPLC grade acetonitrile.

High performance liquid chromatography-mass spectroscopy (HPLC-MS). A Luna C18 column (Phenomenox, Torance, CA), $150 \times 2.0 \mathrm{~mm}$ with $5 \mu \mathrm{m}$ particles was used in all separations. The mobile phase was acetonitrile and water (containing $1 \%$ formic acid, v/v). The gradient began at $95 \%$ water for $3 \mathrm{~min}$, increased to $95 \%$ acetonitrile over the next $10 \mathrm{~min}$ and then held for $5 \mathrm{~min}$. The system was ramped down to $95 \% / 5 \%\left(\mathrm{H}_{2} \mathrm{O} /\right.$ acetonitrile $)$ in $1 \mathrm{~min}$ and then equilibrated for an additional $5 \mathrm{~min}$ for a total analysis time of $22 \mathrm{~min}$. All samples were injected using a Thermo Survey Autosampler. Injection volume was $20 \mu 1$ at a concentration of $100 \mathrm{ng} / \mu \mathrm{l}$. The HPLC column effluent was pumped directly without any split into a Thermo Instrument TSQ triple quadrupole mass spectrometer (Thermo Finnigan, San Jose, CA) equipped with ESI source, which was used in positive ion MS mode. 
Electrochemistry. Cyclic voltammetry was performed in a one compartment, three electrode cell utilizing a platinum disc working electrode, platinum wire auxiliary electrode and $\mathrm{Ag} / \mathrm{AgCl}(\mathrm{NaCl}, 3 \mathrm{M})$ reference electrode calibrated against $\mathrm{FeCp}_{2} / \mathrm{FeCp}_{2}{ }^{+}(0.46 \mathrm{~V}$ vs $\mathrm{Ag} / \mathrm{AgCl})$ with an Epsilon potentiostat from Bioanalytical System, Inc. Measurements were recorded at 0.1 $\mathrm{V} / \mathrm{s}$ in $\mathrm{CH}_{3} \mathrm{CN}$ with $0.1 \mathrm{M} \mathrm{Bu}_{4} \mathrm{NPF}_{6}$ at $\mathrm{RT}$ degassed by bubbling with argon. The working electrode was polished with alumina paste prior to analysis.

Electronic Absorption Spectroscopy. Electronic absorption spectroscopy was performed using an Agilent $8453 \mathrm{UV}$-Vis spectrophotometer with a diode array having $1 \mathrm{~nm}$ resolution and a spectral range of 190 to $1100 \mathrm{~nm}$. Spectra were measured in a $1 \mathrm{~cm}$ quartz cuvette in $\mathrm{CH}_{3} \mathrm{CN}$ at RT. Extinction coefficient determination was performed in triplicate.

DNA Gel Shift Assay. DNA-complex solutions were prepared in aqueous $10 \mathrm{mM}$ phosphate buffer (pH=7.4) with $100 \mu \mathrm{M}$ pUC19 DNA and $20 \mu \mathrm{M}$ tested compound (5:1 base pairs:metal complex). Photolysis was performed for $1 \mathrm{~h}$ with a $455 \mathrm{~nm}$ LED array (for blue light excitation) or a $625 \mathrm{~nm}$ LED array (for red excitation). Oxygen depleted samples were bubbled with argon for 20 minutes prior to photolysis and closed under an argon atmosphere. Dark controls were incubated in a dark compartment while the photolysis was being conducted. All samples were diluted with $10 \mathrm{mM}$ phosphate buffer and loading dye was added. Samples were loaded into a $0.8 \%$ w/w agarose gel with TB buffer (90 mM tris base, $90 \mathrm{mM}$ boric acid), placed in a Owl Separation Systems model B1A stage and electrophoresis was conducted for 90 min at $100 \mathrm{~V}$. Gels were stained in $0.5 \mu \mathrm{g} / \mathrm{ml}$ ethidium bromide (Biotium Inc.) for $30 \mathrm{~min}$, washed using deionized water for $15 \mathrm{~min}$ and visualized on a Fisher Biotech UV-transilluminator. Images were captured using an Olympus SP-320 camera fitted with an ethidium bromide filter.

Protein Gel Shift Assay. BSA-complex solution were prepared in aqueous $10 \mathrm{mM}$ phosphate buffer ( $\mathrm{pH}=7.4)$ with $5 \mu \mathrm{M}$ BSA and $50 \mu \mathrm{M}$ tested compound (1:10 protein:metal complex). Photolysis was performed for $1 \mathrm{~h}$ and $2 \mathrm{~h}$ using a $625 \mathrm{~nm}$ LED array. Dark controls were incubated in a dark compartment while the photolysis was being conducted. Electrophoresis was performed using $1 \mathrm{~mm} \mathrm{4-12 \%} \mathrm{Bis-Tris} \mathrm{gels} \mathrm{(Invitrogen).} \mathrm{Gels} \mathrm{were} \mathrm{loaded} \mathrm{with} \mathrm{samples} \mathrm{treated}$ with Nupage LDS buffer and Nupage reducing agent according to manufacturer's instructions, followed by running in MES buffer at $200 \mathrm{~V}$ for 35 minutes. Gels were washed 3 times with 
water for five minutes before being treated with Simplyblue Safestain (Invitrogen) for one hour. Gels were then washed overnight in water and imaged using a Bio-Rad ChemiDoc XLS system.

Cell Culture. F98 rat malignant glioma cells (ATCC) were maintained in DMEM supplemented with $10 \%$ fetal bovine serum (FBS, ATCC) and 1\% penicillin-streptomycin and incubated at $37^{\circ} \mathrm{C}$ in a humidified incubator at $5 \% \mathrm{CO}_{2}$.

Photocytotoxicity. F98 rat malignant glioma cells were plated in triplicates in the inner 60 wells of a 96-well plate at a density of approximately 10,000 cells per well along with DMEM and incubated at $37^{\circ} \mathrm{C}$ and $5 \% \mathrm{CO}_{2}$ for $24 \mathrm{~h}$ before the treatment. Medium was removed and cells were then incubated for $1 \mathrm{~h}$ with desired concentrations of the compounds. After that, medium was removed, cells were washed with PBS and supplemented with fresh media. The cells were incubated for another 12-16 h prior to $1 \mathrm{~h}$ photolysis in a blue $(470 \mathrm{~nm})$ or red $(625 \mathrm{~nm})$ LED array. The LED array remained inside an incubator set to $37^{\circ} \mathrm{C}$ and $5 \% \mathrm{CO}_{2}$. A thermocouple was placed inside the LED array to monitor the temperature around the cells. Dark controls were treated under the same conditions except the photolysis step. Viability in each well was measured $48 \mathrm{~h}$ after photolysis with an AlamarBlue cell viability assay by monitoring absorbance at 570 and $600 \mathrm{~nm}$.

\section{Results and Discussion}

Synthesis. Compounds 1 and 2 were synthesized by a building block method. In general, the prepared $\left[\left(\mathrm{Ph}_{2} \text { phen }\right)_{2} \mathrm{MCl}_{2}\right](\mathrm{M}=\mathrm{Ru} / \mathrm{Os})$ reacted with excess ligand dpp leading to the crude product, which is purified by alumina chromatography. Characterization using ESI-MS, electronic absorption and electrochemistry matches the previous reported results. ${ }^{18}$ Elemental analysis matched the theoretical composition of both compounds, while HPLC-MS confirms their high purity.

Electrochemistry. The electrochemical properties of monometallic complexes were studied using cyclic voltammetry (Figure 4$)$. The $\mathrm{Ru}$ analog, $\left[\left(\mathrm{Ph}_{2} \text { phen }\right)_{2} \mathrm{Ru}(\mathrm{dpp})\right]\left(\mathrm{PF}_{6}\right)_{2}$, displays a reversible $\mathrm{Ru}^{\mathrm{II} / \mathrm{III}}$ oxidation at $+1.42 \mathrm{~V}$ vs. $\mathrm{Ag} / \mathrm{AgCl}$, and reversible $\mathrm{dpp}^{0 /-}, \mathrm{Ph}_{2} \mathrm{phen}^{0 /-}, \mathrm{Ph}_{2} \mathrm{phen}^{0 /-}$ reductions at $-1.02 \mathrm{~V},-1.37 \mathrm{~V}$ and $-1.56 \mathrm{~V}$, respectively, consistent with previous reports (Table 
1). ${ }^{18}$ Upon changing the metal center from $\mathrm{Ru}$ to Os, a reversible Os ${ }^{\mathrm{II} / \mathrm{III}}$ oxidation is observed at $+0.96 \mathrm{~V}$, and reversible $\mathrm{dpp}^{0 /-}, \mathrm{Ph}_{2} \mathrm{phen}^{0 /-}, \mathrm{Ph}_{2} \mathrm{phen}^{0 /-}$ reductions at $-0.99 \mathrm{~V},-1.30 \mathrm{~V}$ and $-1.55 \mathrm{~V}$.

The redox properties of the monometallic complexes provide insight into the relative orbital energetics. For both compounds, the highest occupied molecular orbital, HOMO, is localized on the metal-based $(\mathrm{d} \pi)$ with the lowest unoccupied molecular orbital, LUMO, localized on the $\operatorname{dpp}\left(\pi^{*}\right)$. This predicts a lowest lying $\mathrm{Os} / \operatorname{Ru}(\mathrm{d} \pi) \rightarrow \operatorname{dpp}\left(\pi^{*}\right)$ MLCT transition in the electronic absorption spectroscopy. The higher energy $\operatorname{Os}(\mathrm{d} \pi)$ orbital results in a smaller energy gap between HOMO and LUMO compared to the Ru congener, predicting a lower energy MLCT absorption band for the Os compound.

Table 1. Electrochemical Data for compound 1 and $\mathbf{2}^{\text {a }}$

\begin{tabular}{lll} 
Complex & $\mathbf{E}_{\mathbf{1 / 2}}{ }^{\mathbf{o x}}(\mathbf{V})$ & $\mathbf{E}_{\mathbf{1 / 2}}{ }^{\text {red }}(\mathbf{V})$ \\
\hline $\mathbf{1}$ & $+1.40 \mathrm{Ru}^{\mathrm{II} / \mathrm{III}}$ & $-1.02 \mathrm{dpp}^{0 /-}$ \\
& $-1.37 \mathrm{Ph}_{2} \mathrm{phen}^{0 /-}$ \\
& $-1.56 \mathrm{Ph}_{2} \mathrm{phen}^{0 /-}$ \\
\hline $\mathbf{2}$ & $-0.99 \mathrm{dpp}^{0 /-}$ \\
& $-1.30 \mathrm{Ph}_{2} \mathrm{phen}^{0 /-}$ \\
& $-1.55 \mathrm{Ph}_{2} \mathrm{phen}^{\mathrm{II/III}}$
\end{tabular}

${ }^{\mathrm{a}}$ Measurements recorded at $\mathrm{RT}$ under $\mathrm{Ar}$ in $\mathrm{CH}_{3} \mathrm{CN}$ with $0.1 \mathrm{M} \mathrm{Bu}_{4} \mathrm{NPF}_{6}$ electrolyte. 


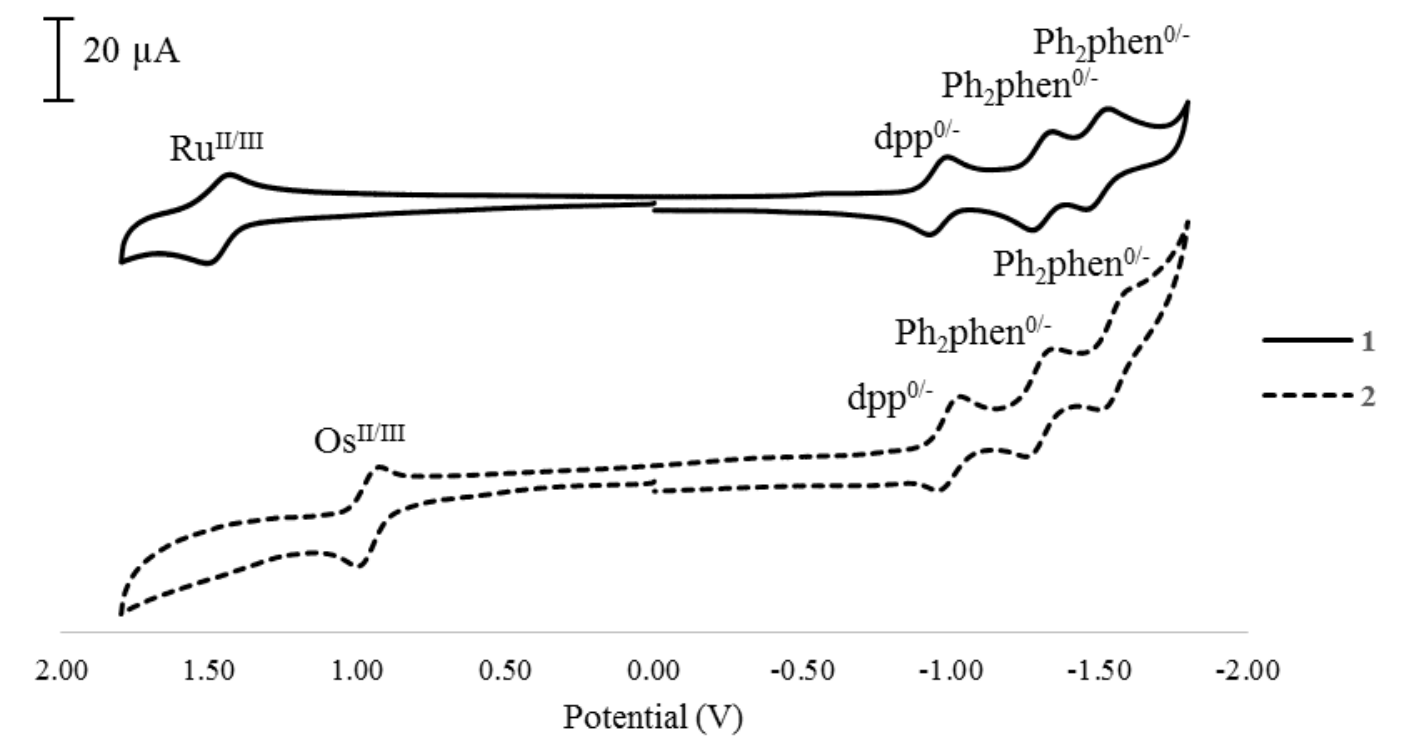

Figure 4. Cyclic voltammogram of 1 and 2 at $\mathrm{RT}$ under $\mathrm{Ar}$ in $0.1 \mathrm{M} \mathrm{Bu}_{4} \mathrm{NPF}_{6}$ acetonitrile, $\mathrm{E}$ vs. $\mathrm{Ag} / \mathrm{AgCl}$.

Electronic Absorption Spectroscopy. Electronic absorption spectroscopy of the new PDT agents was investigated to evaluate their light absorbing properties. Both complexes display intense absorption through the UV and visible region (Figure 5). For compound 1, the UV region is dominated by intraligand ( $\left.{ }^{1} \mathrm{IL}\right) \pi \rightarrow \pi^{*}$ transitions, with $\lambda^{\text {abs }}=279 \mathrm{~nm}\left(73700 \mathrm{M}^{-1} \mathrm{~cm}^{-1}\right.$ ) for $\mathrm{Ph}_{2}$ phen $\pi \rightarrow \pi^{*}$ transitions and $\lambda^{\mathrm{abs}}=320 \mathrm{~nm}\left(24400 \mathrm{M}^{-1} \mathrm{~cm}^{-1}\right)$ for dpp $\pi \rightarrow \pi^{*}$ transitions. In the visible region, singlet metal-to-ligand charge transfer $\left({ }^{1} \mathrm{MLCT}\right)$ transitions are observed with $\mathrm{Ru}(\mathrm{d} \pi) \rightarrow \mathrm{Ph}_{2}$ phen $\left(\pi^{*}\right) \mathrm{CT}$ transitions occurring at $424 \mathrm{~nm}\left(\varepsilon=14800 \mathrm{M}^{-1} \mathrm{~cm}^{-1}\right)$, followed by $\mathrm{Ru}(\mathrm{d} \pi) \rightarrow \operatorname{dpp}\left(\pi^{*}\right) \mathrm{CT}$ transitions at $474 \mathrm{~nm}\left(\varepsilon=15000 \mathrm{M}^{-1} \mathrm{~cm}^{-1}\right)$. For compound 2 , very similar intraligand transitions have been observed in the UV region, with a slightly higher molar absorptivity at $279 \mathrm{~nm}\left(105200 \mathrm{M}^{-1} \mathrm{~cm}^{-1}\right)$ and $320 \mathrm{~nm}\left(34900 \mathrm{M}^{-1} \mathrm{~cm}^{-1}\right)$. In the visible region, ${ }^{1}$ MLCT red shifts to Os $(\mathrm{d} \pi) \rightarrow \mathrm{Ph}_{2}$ phen $\left(\pi^{*}\right) \mathrm{CT}$ at $444 \mathrm{~nm}\left(\varepsilon=22700 \mathrm{M}^{-1} \mathrm{~cm}^{-1}\right)$, followed by $\operatorname{Os}(\mathrm{d} \pi) \rightarrow \mathrm{dpp}\left(\pi^{*}\right) \mathrm{CT}$ transitions at $494 \mathrm{~nm}\left(\varepsilon=22000 \mathrm{M}^{-1} \mathrm{~cm}^{-1}\right)$. The bathochromic shift observed for $\mathbf{2}$ agrees with the trend predicted from the electrochemistry of the compounds. Also, compound 2 exhibits a broad ${ }^{3}$ MLCT absorbance centered at $650 \mathrm{~nm}\left(\varepsilon=4829 \mathrm{M}^{-1} \mathrm{~cm}^{-1}\right)$, which is 24 times higher than the Ru congener due to a larger degree of spin-orbit coupling. This low-energy visible light absorption provides the possibility for photoactivation in the therapeutic window. 


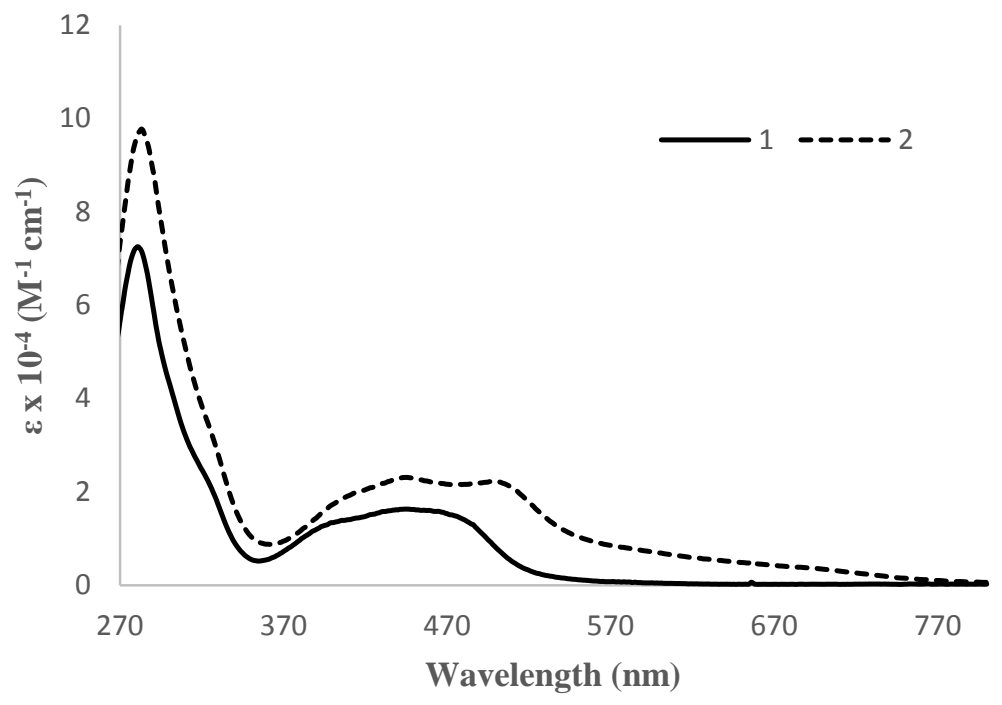

Figure 5. Electronic absorption spectra of $1\left[\left(\mathrm{Ph}_{2} \mathrm{phen}\right)_{2} \mathrm{Ru}(\mathrm{dpp})\right]\left(\mathrm{PF}_{6}\right)_{2}$ (solid line) and 2 $\left[\left(\mathrm{Ph}_{2} \text { phen }\right)_{2} \mathrm{Os}(\mathrm{dpp})\right]\left(\mathrm{PF}_{6}\right)_{2}$ (dashed line) in DMF at RT.

Table 2. Summary of Light-Absorbing Properties

\begin{tabular}{|c|c|c|c|}
\hline Compound & $\lambda^{\text {abs }}(\mathbf{n m})$ & $\varepsilon \times 10^{-4}\left(\mathrm{M}^{-1} \mathrm{~cm}^{-1}\right)$ & Assignment \\
\hline \multirow[t]{4}{*}{$\mathbf{1}$} & 279 & 7.37 & $\mathrm{Ph}_{2}$ phen $\pi \rightarrow \pi^{*}$ \\
\hline & 320 & 2.44 & $\operatorname{dpp} \pi \rightarrow \pi^{*}$ \\
\hline & 424 & 1.48 & $\mathrm{Ru}(\mathrm{d} \pi) \rightarrow \mathrm{Ph}_{2}$ phen $\left(\pi^{*}\right) \mathrm{CT}$ \\
\hline & 474 & 1.50 & $\operatorname{Ru}(\mathrm{d} \pi) \rightarrow \operatorname{dpp}\left(\pi^{*}\right) \mathrm{CT}$ \\
\hline \multirow[t]{4}{*}{2} & 279 & 10.52 & $\mathrm{Ph}_{2}$ phen $\pi \rightarrow \pi^{*}$ \\
\hline & 320 & 3.49 & $\operatorname{dpp} \pi \rightarrow \pi^{*}$ \\
\hline & 444 & 2.27 & $\mathrm{Os}(\mathrm{d} \pi) \rightarrow \mathrm{Ph}_{2} \operatorname{phen}\left(\pi^{*}\right) \mathrm{CT}$ \\
\hline & 494 & 2.2 & $\operatorname{Os}(\mathrm{d} \pi) \rightarrow \operatorname{dpp}\left(\pi^{*}\right) \mathrm{CT}$ \\
\hline
\end{tabular}


DNA gel shift assay. The activity of compounds $\mathbf{1}$ and $\mathbf{2}$ towards supercoiled plasmid DNA was probed under dark and light conditions. As presented in Figure 6.A, the untreated pUC19 DNA (lane 2) contains mostly of the supercoiled (SC) form of the plasmid, which displays an apparent electrophoretic size of ca. $2000 \mathrm{bp}$, along with a small amount of open circular (OC) DNA, with an apparent size of 4000 bp. Incubation of this template with compounds 1 or 2 at room temperature in a dark compartment (lanes 3 and 6) for 1 hour yielded minimum to undetectable change in the electrophoretic profile of the DNA, which is attributed to negligible covalent modification of the biomolecule in the absence of light. In contrast, excitation with blue light for the same period of time (lanes 4 and 7) yielded an apparent increase in the amount of the OC form, which is attributed to single strand cleavage. Furthermore, compound $\mathbf{1}$ produced a higher degree of DNA scission than 2. This is not surprising given that $\mathbf{1}$ has been reported to have a 20 -fold higher excited state lifetime than $\mathbf{2}$ at room temperature, ${ }^{18}$ thus providing a larger spatial diffusion radius and greater probability of colliding with a DNA molecule while in the excited state. The activity of both compounds decreased when oxygen was purged from the solutions prior to photolysis, thus suggesting a predominantly oxygen-dependent mechanism for DNA scission, such as the formation of ROS. However, cleavage activity was not completely inhibited which could be attributed to either incomplete oxygen removal by the procedure herein utilized, or direct DNA scission by the excited state of the compounds.

Interestingly, the relative activity of compounds $\mathbf{1}$ and $\mathbf{2}$ under red light excitation is inversed. As observed in Figure 6.B, photolysis of 2 with $625 \mathrm{~nm}$ light generated a higher amount of OC DNA than 1 (lanes 5 and 6 respectively). This behaviour is attributed to the higher extinction coefficient presented by the osmium congener at the longer excitation wavelength, due to its higher degree of spin-orbit coupling. Given that $\mathbf{2}$ absorbs light more efficiently upon irradiation, more molecules are promoted into the excited state and thus, are allowed to react either with ${ }^{3} \mathrm{O}_{2}$ or DNA. Irradiation time for both samples was increased to 2 hours to further proof the photodynamic effect. Once again, DNA cleavage promoted by 2 is only observed after photoactivation (lanes 2, 4 compared to lane 6 in gel B), whereas the extend of photoscission is proportional to photolysis time (lane 6 vs lane 8 ).. 


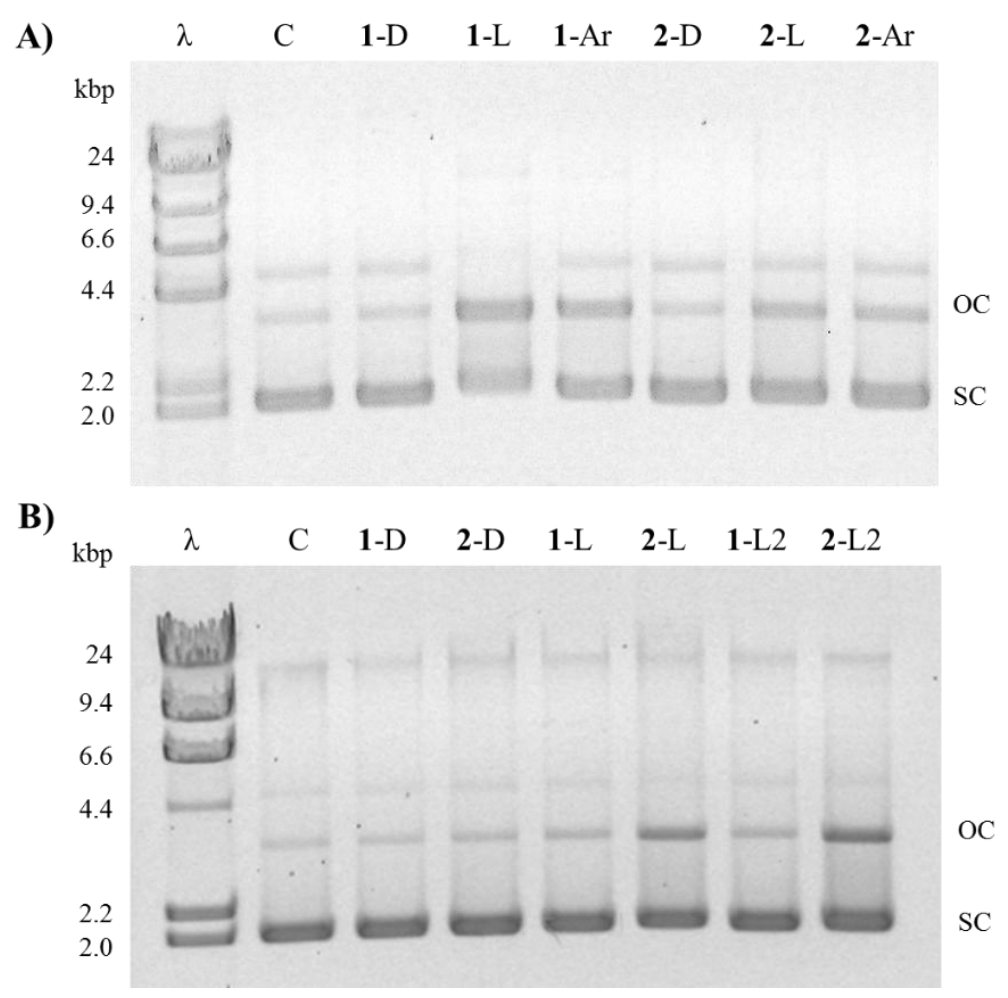

Figure 6. DNA gel shift assay. $\lambda=$ Lamba DNA/Hind III markers. $C=$ untreated pUC19 DNA control. $D=$ sample incubated in dark conditions for $1 \mathrm{~h}$ (gel A) or $2 \mathrm{~h}$ (gel B). L= sample irradiated for $1 \mathrm{~h}$ with blue light $(455 \mathrm{~nm}$, gel A) or red light $(625 \mathrm{~nm}$, gel B). L2= sample irradiated for $2 \mathrm{~h}$ with red light $(625 \mathrm{~nm})$, $\operatorname{Ar}=$ oxygen depleted samples purged with argon prior to $1 \mathrm{~h}$ irradiation with blue light.

Protein gel shift assay. The activity of compounds $\mathbf{1}$ and $\mathbf{2}$ towards proteins was investigated under dark and light conditions by using BSA as a model protein. As shown in Figure 7.A, incubation of BSA with compounds $\mathbf{1}$ and $\mathbf{2}$ in a dark compartment for $2 \mathrm{~h}$ yielded undetectable changes in the electrophoretic profile of BSA, probably due to the negligible interaction between the compounds and BSA in the absence of light, which agrees with the results obtained in the DNA experiments described above. In contrast, excitation with red light for 1 or $2 \mathrm{~h}$ resulted in apparent changes in the electrophoretic profile of BSA. To be specific, the bands were found to be less homogeneous and shift to low molecular weight positions, which may be attributed to cleavage and degradation caused by photoactivation (e.g. generation of ROS or direct photoreactivity, vide infra). Moreover, the profile change promoted by compound $\mathbf{2}$ was more marked than that of compound $\mathbf{1}$ in the presence of red light $(625 \mathrm{~nm})$, suggesting that compound 
$\mathbf{2}$ had higher activity toward BSA over compound 1, which is in consistent with the DNA and cytotoxicity data.
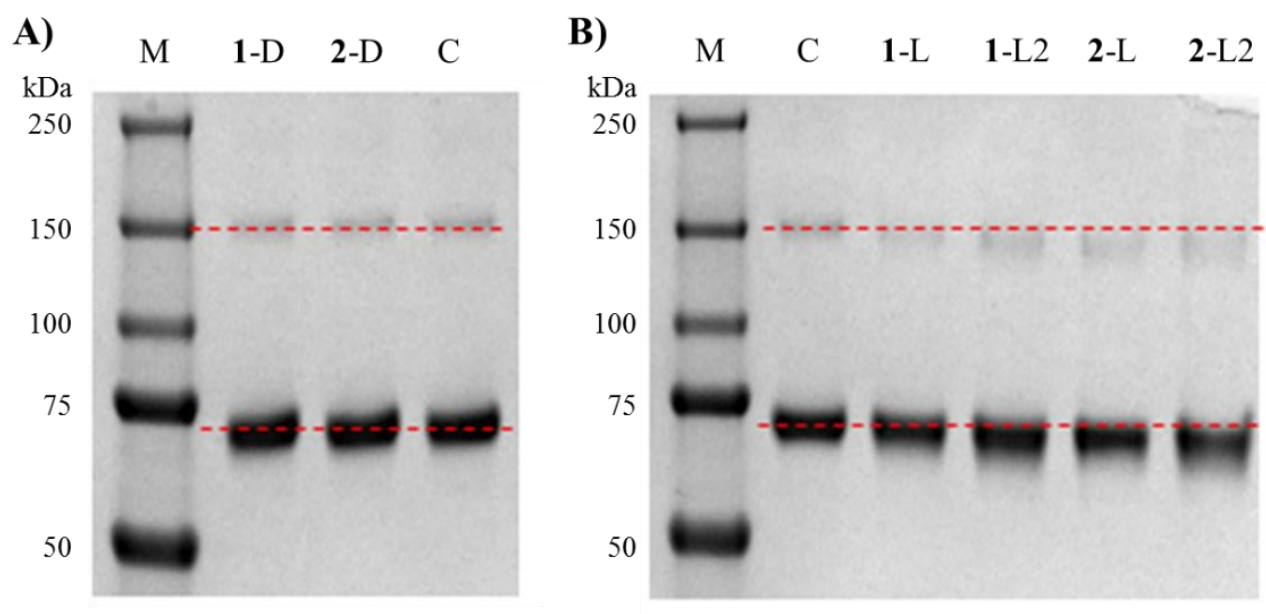

Figure 7. Protein gel shift assay. $M=$ ladder. $C=$ untreated BSA control. $D=$ samples incubated in the dark for $2 \mathrm{~h}$. L=sample irradiated for $1 \mathrm{~h}$ with red light $(625 \mathrm{~nm})$. L2=sample irradiated for $2 \mathrm{~h}$ with red light $(625 \mathrm{~nm})$.

Cytotoxicity. The photocytotoxic activity of compounds $\mathbf{1}$ and $\mathbf{2}$ was evaluated in malignant glioma F98 rat cells in terms of its $\mathrm{IC}_{50}$ value by the AlamarBlue assay. Cisplatin, an FDA approved systemic chemotherapy drug, was used for comparison. Given its poor light absorption, cisplatin exhibited the same activity under light and dark conditions. The $\mathrm{IC}_{50}$ value stayed at (256 \pm 4.0$) \mu \mathrm{M}$ under dark and blue light irradiation. As shown in Figure 8, compounds 1 and 2 were found to be nontoxic in the dark up to the highest concentration tested in this work (500 $\mu \mathrm{M}$ ), since the viable cell percentage were higher than $80 \%$ after the treatment. In contrast, a phototoxic effect was observed upon visible light activation. For compound $\mathbf{1}$, the $\mathrm{IC}_{50}$ values were calculated as $(68.7 \pm 1.9)$ and $(337.1 \pm 18.5) \mu \mathrm{M}$ under blue light $(470 \mathrm{~nm})$ and red light (625 $\mathrm{nm}$ ) irradiation, respectively. The lower efficacy displayed at the latter conditions was attributed to decreased light absorption at longer wavelengths, as observed in its electronic absorption spectrum (Figure 5). For compound 2, the PDT effect is more significant, with $\mathrm{IC}_{50}$ values of (50.7 \pm 2.9$) \mu \mathrm{M}$ in blue light and $(86.1 \pm 8.5) \mu \mathrm{M}$ in red light. Interestingly but not surprisingly, altering the metal center from $\mathrm{Ru}$ to Os makes compound $\mathbf{2}$ more cytotoxic under activation 
within the phototherapeutic window $(600-900 \mathrm{~nm})$, attributed to a higher molar absorptivity at the irradiation wavelength. Upon photon absorption, the molecule populates a reactive excited state that might lead to the generation of reactive oxygen species, as suggested by the gel electrophoresis experiment, which would favour the oxidation of molecular targets (i.e. DNA or proteins) and lead to cell death. Although the detailed cell death mechanism is still unknown and needs to be further studied, it could potentially involve ROS and oxidation or degradation of biomolecules. More prominently, both complexes show remarkably higher photocytotoxicity than cisplatin towards aggressive Rat malignant glioma F98 cells.

Table 3. Photocytotoxicity study in F98 cells

\begin{tabular}{|c|c|c|c|}
\hline \multirow{2}{*}{ Compound } & \multicolumn{3}{|c|}{ IC $_{\mathbf{5 0}}(\boldsymbol{\mu M})$} \\
\cline { 2 - 4 } & Dark & Blue & Red \\
\hline $\mathbf{1}$ & $>500$ & $68.7 \pm 1.9$ & $337.1 \pm 18.5$ \\
\hline $\mathbf{2}$ & $>500$ & $50.7 \pm 2.9$ & $86.1 \pm 8.5$ \\
\hline $\mathbf{3}$ & $256 \pm 4.0$ & $256 \pm 4.0$ & N.D \\
\hline
\end{tabular}

A)

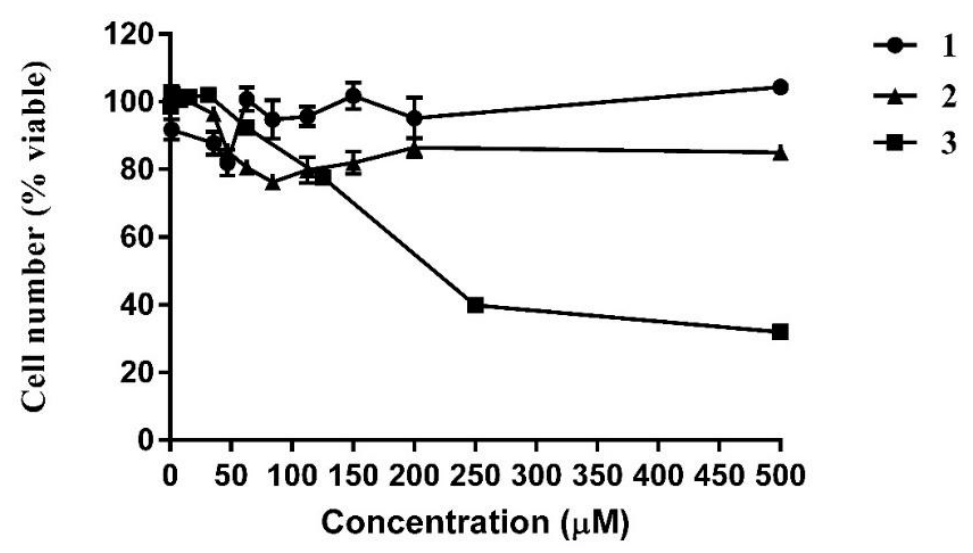


B)

C)
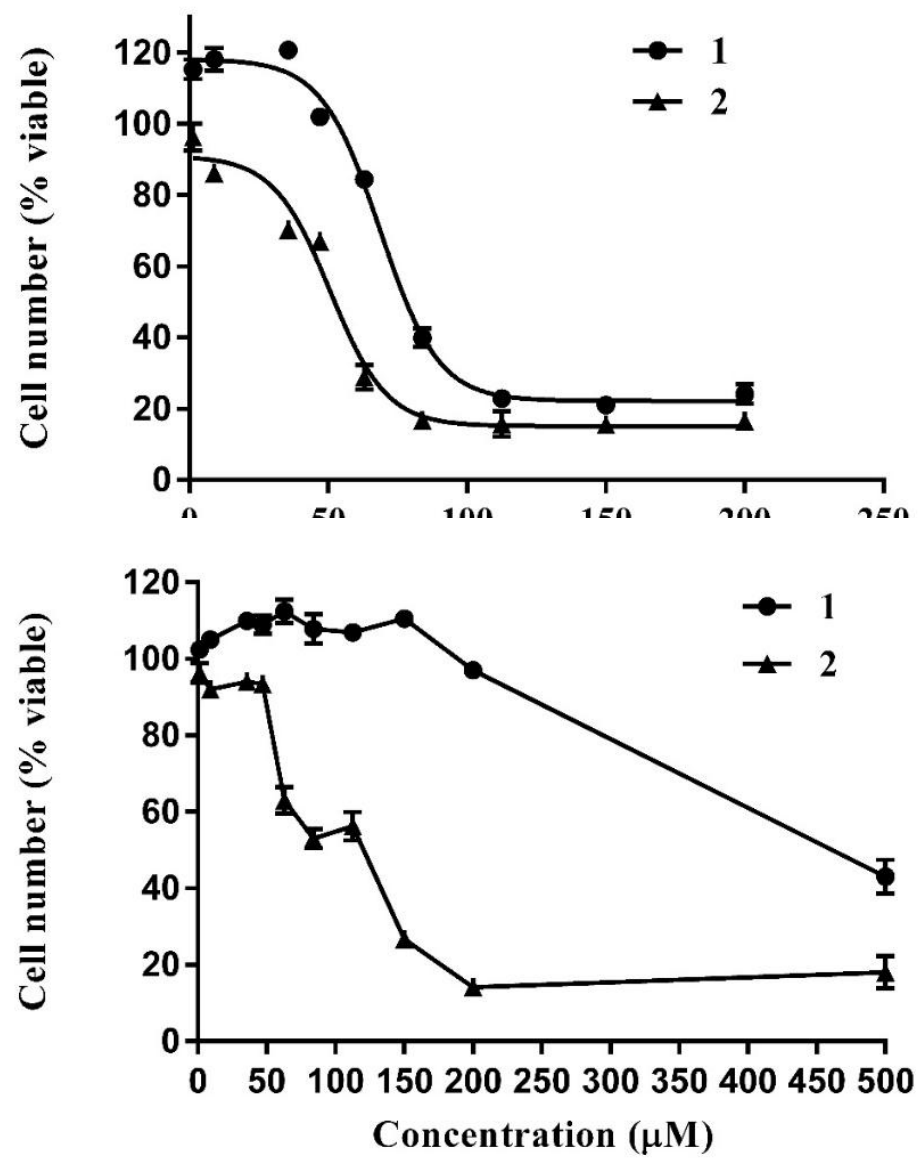

Figure 8. Cytotoxicity graphed as percent cell viability of F98 cells vs compound concentration ( $\mu \mathrm{M}) 48$ $\mathrm{h}$ after treatment. A) In the dark. B) Blue light $(470 \mathrm{~nm})$ irradiation for $1 \mathrm{~h}$. C) Red light $(625 \mathrm{~nm})$ irradiation for $1 \mathrm{~h}$. Each data point was performed in triplicate.

Conclusion. We present two new Ru/Os polyazine complexes as potential PDT agents towards aggressive rat malignant glioma F98 cells and photoactivated oxygen-dependent DNA and protein cleaving reagents. Both compounds have shown significant photocytotoxicity to F98 MG cells under short time $(1 \mathrm{~h})$ low power $(3.75 \mathrm{~mW})$ blue and red light activation, with relative low $\mathrm{IC}_{50}$ values compared to cisplatin. Metal center change from $\mathrm{Ru}$ to Os resulted in a higher degree of spin-orbit coupling and enhanced absorption within the phototherapeutic window, thus 
making compound $\mathbf{2}$ a promising PDT candidate for clinical application. This work demonstrates a simple strategy to tune transition metal complexes towards low energy light activation. Moreover, presence of the bridging ligand $\mathrm{dpp}$ in the reported compounds provides the possibility for further supramolecular design of multifunctional PDT agents.

\section{Acknowledgements}

The authors are grateful to the National Science Foundation (grant CHE-1301131) for funding this work. Acknowledgement is made to Dr. Amanda J. Morris and Theodore Canterbury for helpful discussion. Special Acknowledgement is made to Prof. Karen.J.Brewer, who passed away but left precious memories and immortal inspiration as a good mentor and friend.

\section{Notes}

${ }^{a}$ Department of Chemistry, Virginia Tech., Blacksburg, Virginia 24061-0212, USA.

${ }^{b}$ School of Biomedical Engineering and Sciences, Virginia Tech., Blacksburg, Virginia 24061-0212, USA.

${ }^{c}$ Department of Biological Systems Engineering, Virginia Tech ,Blacksburg, Virginia 24061-0212, USA.

†:Deceased, October 24, 2014

$\dagger$ :Correspondence to Jie Zhu at the Virginia Polytechnic Institute and State University, Department of Chemistry, Blacksburg, VA 24061-0212, USA. Email: zjie12@ vt.edu; Tel: 540200-5528

\section{References}

1. Celli, J. P.; Spring, B. Q.; Rizvi, I.; Evans, C. L.; Samkoe, K. S.; Verma, S.; Pogue, B. W.; Hasan, T. Chem. Rev. 2010, 110 (5), 2795-2838.

2. Castano, A. P.; Demidova, T. N.; Hamblin, M. R. Photodiagn. Photodyn. Ther. 2004, 1 (4), 279-293. 
3. Detty, M. R.; Gibson, S. L.; Wagner, S. J. J. Med. Chem. 2004, 47 (16), 3897-915.

4. (a) DeRosa, M. C.; Crutchley, R. J. Coord. Chem. Rev. 2002, 233-234, 351-371; (b) Lovell, J. F.; Liu, T. W. B.; Chen, J.; Zheng, G. Chem. Rev. 2010, 110 (5), 2839-2857.

5. Bonnett, R., Chemical aspects of photodynamic therapy. CRC Press: 2000.

6. (a) van Rijt, S. H.; Sadler, P. J. Drug Discovery Today 2009, 14 (23-24), 1089-1097; (b) Holder, A. A.; Zigler, D. F.; Tarrago-Trani, M. T.; Storrie, B.; Brewer, K. J. Inorg. Chem. 2007, 46 (12), 4760-4762.

7. (a) Erkkila, K. E.; Odom, D. T.; Barton, J. K. Chem. Rev. 1999, 99 (9), 2777-2796; (b) Sun, Y.; Joyce, L. E.; Dickson, N. M.; Turro, C. Chem. Commun. 2010, 46 (14), 2426-2428; (c) Howerton, B. S.; Heidary, D. K.; Glazer, E. C. J. Am. Chem. Soc. 2012, 134 (20), 8324-8327.

8. Zigler, D. F.; Brewer, K. J., Towards Photodynamic Therapy of Cancer with Platinum Group Metal Polyazine Complexes. In Metal Complex-DNA Interactions, John Wiley \& Sons, Ltd: 2009; pp 235-272.

9. (a) Sun, Y.; Joyce, L. E.; Dickson, N. M.; Turro, C. Chem. Commun. 2010, 46 (36), 6759-6761; (b) Wang, J.; Newman, J., Jr.; Higgins, S. L.; Brewer, K. M.; Winkel, B. S.; Brewer, K. J., Angew. Chem., Int. Ed. 2013, 52 (4), 1262-5; (c) Higgins, S. L. H.; Tucker, A. J.; Winkel, B. S. J.; Brewer, K. J. Chem. Commun. 2012, 48 (1), 67-69; (d) Wachter, E.; Heidary, D. K.; Howerton, B. S.; Parkin, S.; Glazer, E. C. Chem. Commun. 2012, 48 (77), 9649-9651.

10. Siegel, R.; Naishadham, D.; Jemal, A. Ca-Cancer J. Clin. 2013, 63 (1), 11-30.

11. Reardon, D. A.; Rich, J. N.; Friedman, H. S.; Bigner, D. D. J. Clin. Oncol. 2006, 24 (8), 1253-65.

12. (a) Sathornsumetee, S.; Reardon, D. A.; Desjardins, A.; Quinn, J. A.; Vredenburgh, J. J.; Rich, J. N. Cancer 2007, 110 (1), 13-24; (b) Furnari, F. B.; Fenton, T.; Bachoo, R. M.; Mukasa, A.; Stommel, J. M.; Stegh, A.; Hahn, W. C.; Ligon, K. L.; Louis, D. N.; Brennan, C.; Chin, L.; DePinho, R. A.; Cavenee, W. K. Genes Dev. 2007, 21 (21), 2683-2710.

13. Ohgaki, H.; Dessen, P.; Jourde, B.; Horstmann, S.; Nishikawa, T.; Di Patre, P. L.; Burkhard, C.; Schuler, D.; Probst-Hensch, N. M.; Maiorka, P. C.; Baeza, N.; Pisani, P.; Yonekawa, Y.; Yasargil, M. G.; Lutolf, U. M.; Kleihues, P. Cancer Res. 2004, 64 (19), 6892-9.

14. Kanzawa, T.; Germano, I. M.; Komata, T.; Ito, H.; Kondo, Y.; Kondo, S. Cell Death Differ. 2004, 11 (4), 448-457. 
15. (a) Aguirre, J. D.; Angeles-Boza, A. M.; Chouai, A.; Pellois, J.-P.; Turro, C.; Dunbar, K. R. J. Am. Chem. Soc. 2009, 131 (32), 11353-11360; (b) Basu, U.; Khan, I.; Hussain, A.; Kondaiah, P.; Chakravarty, A. R. Angew. Chem., Int. Ed. 2012, 51 (11), 2658-2661; (c) Holder, A. A.; Swavey, S.; Brewer, K. J. Inorg. Chem. 2004, 43 (1), 303-308.

16. (a) Ye, R.-R.; Tan, C.-P.; Lin, Y.-N.; Ji, L.-N.; Mao, Z.-W. Chem. Commun. 2015, 51 (39), 8353-8356; (b) Draksharapu, A.; Boersma, A. J.; Leising, M.; Meetsma, A.; Browne, W. R.; Roelfes, G. Dalton Trans. 2015, 44 (8), 3647-3655.

17. (a) Dickerson, M.; Sun, Y.; Howerton, B.; Glazer, E. C. Inorg. Chem. 2014, 53 (19), 10370-10377; (b) Basu, U.; Khan, I.; Hussain, A.; Gole, B.; Kondaiah, P.; Chakravarty, A. R. Inorg. Chem. 2014, 53 (4), 2152-2162; (c) Yuan, Y.-X.; Chen, Y.; Wang, Y.-C.; Su, C.-Y.; Liang, S.-M.; Chao, H.; Ji, L.-N. Inorg. Chem. Commun. 2008, 11 (9), 1048-1050.

18. Mongelli, M. T.; Brewer, K. J. Inorg. Chem. Commun. 2006, 9 (9), 877-881. 


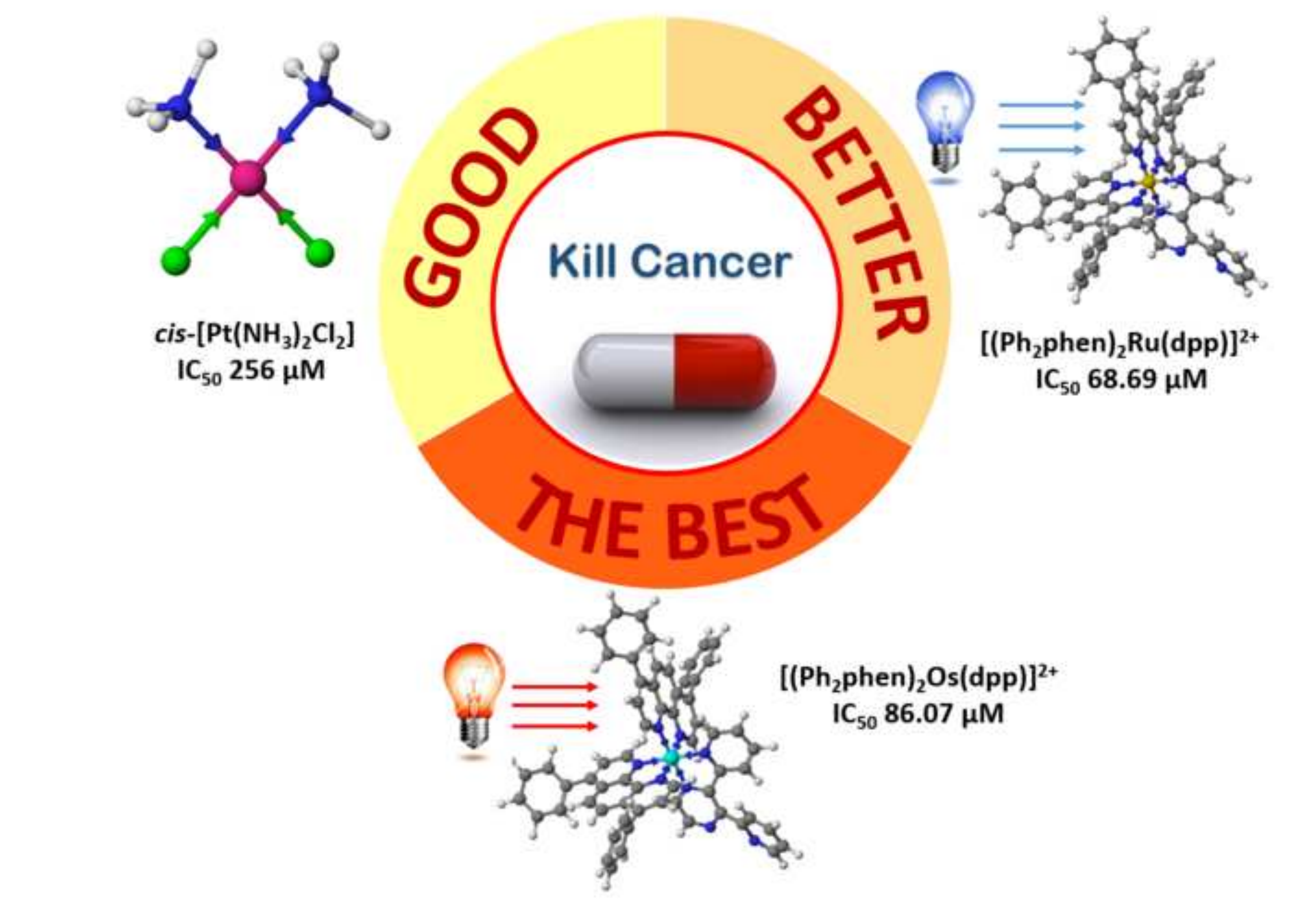

(n)
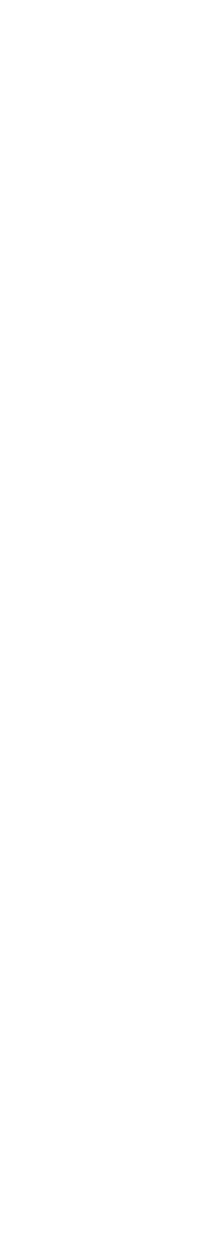

. 